821.161:398.09

https://doi.org/10.18485/msc.2018.47.2.ch3

Оксана МИКИТЕНКО*

Інститут мистецтвознавства, фольклористики та етнології ім. М.Т. Рильського НАН України, Київ
Оригинални научни рад

Примљен: 20. 10. 2017.

Прихваћен: 27. 12. 2017.

\title{
ДОПРИНОС ПЕТРА Г. БОГАТИРЈОВА И НИКИТЕ И. ТОЛСТОЈА ПРОУЧАВАҢУ КАРНЕВАЛИЗАЦИЈЕ У ФОЛКЛОРУ СЛОВЕНА
}

\begin{abstract}
Допринос Петра Г. Богатирјова и Никите И. Толстоја проучавању карневализације у народној култури, посебно поетици карневализације у народној књижевности, очитује се истовремено на теоријско-методолошком и конкретно-предметном плану вишестраних научних истраживања, као и значајним теоријским закључцима, а такође вештини уочавања законитости одређене појаве у сваком фолклорно-етнографском факту (нпр. полазник, бадњак), у исто време разматрајући саоднос „ниске” и „високе” културе. Принцип „функционално-структуралног” проучавања фолклора, који је П. Богатирјов формулисао 1929. у познатој књизи о магијским радњама, обредима и веровањима Закарпатја, а такође поставке његових класичних радова о народном позоришту и позоришним елементима у структури словенског обредног текста, добили су касније наставак и развитак у радовима Н. Толстоја (и московске етнолингвистичке школе) као сведочанство испољавања јединства народне традиције, што је посебно приказано у оквиру семиотике ритуала, имајући у виду семантичку интерпретацију синкретичног фолклорног текста и његових, из аспекта карневализације, релевантних магијских обредних елемената (ритуални смех, маскирање, антипонашање, дијалог, опсцена лексика и сл.).

Кључне речи: карневал, карневализација, фолклор, Петар Богатирјов, Никита Толстој, славистика.

У речнику научне и народне терминологије Восточнославянский фольклор (1993) постоји термин „карневалност”, који се одређује као „низ особина (масовност, уличне поворке маскираних, маскарада, плесови, театрализоване игре, смех, осећање свенародног празника), које стварају атмосферу карневала”, а такође као „приказивање посебног погледа на свет, карактеристичног за народну (фолклорну и средњовековну) културу улице, са представом о јединству опозиција: рођење - смрт, горњи - доњи, похвала - грдња,
\end{abstract}

*oksana_mykytenko@hotmail.com 
плач - смех у основи, које се огледа кроз призму универзалног смеха” (Некрилова 1993: 110). Бахтиновом дефиницијом карневала као „синкретичне представљачке форме обредног карактера” са језиком „симболичких конкретно-чулних форми”, као и термином карневализације - „транспоновања карневала на језик литературе", наглашена је веза књижевности са токовима народне културе и живота. Спадајући у домен књижевности, такође и народне, карневализација истиче такве особине дискурса као смеховни принцип, систем травестија и инверзија, хуморно-иронично и гротескно преокретање света, које се манифестују у мистификацијама, прерушавању, ремећењу пропорција и премештању улога, фамилијарном понашању и говорном изразу и сл. (Речник: 339-340).

Није случајно што су феномени карневала и карневализације као његовог рефлекса и посебног виђења света у усменокњижевном тексту привукли пажњу Петра Богатирјова, који је пратио постојање живе фолклорне традиције у двадесетим годинама XX в. на територији Закарпатја и лично осетио стваралачке и активне токове народне културе. Резултате својих експедицијских и архивских истраживања у западној Украјини Богатирјов је представио у књизи Магические действия, обряды и верования Закарпатья, која се прво појавила 1929. на француском, а 1971. је била преведена на руски језик. „Патос ове књиге”, наглашавао је П. Богатирјов,

[...] је проучавање савременог стања ритуала. Синхрона анализа календарских и породичних обреда и обичаја, приповедања закарпатских сељака о натприродним створењима и појавама показала је да се ради о сталној промени форме и функције етнографских чињеница, и пружила могућност да се спроведе класификација ритуала на основу актуелне магијске функције (Богатирјов 1971: 6)

Овај рад, као и монографија Народный театр чехов и словаков и низ чланака који су ушли у зборник Bопросы теории народного искусства (1971), потврдили су приврженост Петра Богатирјова примени „семиотичких метода у етнографији”, а такође, изабраној још у млађим годинама, „функционално-структуралној методи”, која „доприноси проучавању [...] грађе као материјалне, тако и духовне културе, - бајања, изрека, магијских радњи, прича, песама и сл.” (Богатирјов 1971: 7). Истичући значај синхроне анализе за проучавање „одређеног дела живота ових ритуала, и дакле њихову еволуцију” (Богатирјов 1971: 179), научник је у исто време наглашавао значај историјског аспекта, сматрајући да проучавање са структурно-семиотичког гледишта даје одговор и на „различита питања историјске естетике, појаву одређених жанрова народне уметности, посебно народног позоришта" (Богатирјов 1971: 7). Фолклорна дела из таквог угла посматрања, којим се отварао пут истраживањима у области културно-филолошке (лингвистичке и фолклорне) географије, добијала су, према оцени дугогодишњег друга Богатирјова и коаутора - Романа Јакобсона, не само „најдубљи временски”, него и „најшири просторни дијапазон” (Толстој 2003: 588). Већ у својим првим радовима (реферату на I конгресу словенских етнографа и географа у Прагу 1924. и II конгресу у Пољској 1927.) Богатирјов је изјавио да „у различитим рејонима Закарпатја границе ширења одређених дијалекатских особина у об- 
ласти фонетике, лексике и сл. подударају се са границама ширења етнографских чињеница" (Богатирјов 1971: 171), - теза која ће касније добити свестрану аргументацију и образложење у радовима Никите Толстоја и московске етнолингвистичке школе.

Из својих посматрања Богатирјов је извео закључак да су „посебне врсте народне уметности међусобно повезане и чине јединствену уметничку структуру" (Богатирјов 1971: 9). Роман Јакобсон, сећајући се првих заједничких научних подухвата, запазио је да нам је „анализа фолклорних дела, жанрова и њихова корелација као једне целине, отварала очи за нове проблеме, посебно су се у новом светлу појављивали исконски митолошки мотиви" (Толстој 2003: 588).

Поглед на народну културу као целину био је полазна тачка свих чланова Прашког лингвистичког кружока, посебно у радовима Јана Мукаржовског - аутора бројних истраживања из поетике и структурне естетике и присног пријатеља Богатирјова. Полазећи од структурно-функционалне анализе различитих уметничких и културних врста (филм, архитектура, позориште, фолклор), Мукаржовски је поднео концепцију „семантичког геста” и покренуо проблем „интензионалности” као услов постизања „целокупности” уметничког дела (Зубрицка 1996: 324). Одјек ове теорије налазимо у примедби Богатирјова о „тесној и непосредној вези” гестикулације и позоришног покрета као „карактеристичне особине сељачког и градског фолклора” у чланку „Художественные средства в юмористическом ярмарочном фольклоре" (Богатирјов 1971: 469). Нагласимо да је позната структуралистичко-семиотичка школа из Тартуа касније засновала своје принципе на погледима Мукаржовског, и није случајно што је предговор руском издању радова истакнутог чешког лингвисте написао Јуриј Лотман. Мукаржовски, за којег је Богатирјов увек био ,једноставно Пјотр”, ценио је свог колегу као „личност огромног мерила” и „научника светског гласа", и наводио речи Леви-Брила који му је на једном од научних скупова признао да „између фолклориста целог света овај [Богатирјов] је најдаровитији" (Мукаржовски 2002: 17). Богатирјов је такође у своје време налазио подршку у радовима француског социолога, посебно за своју критику закључака антрополошке школе, који су, према њему, били „испод сваке критике” и донети „из аналогије”.

Треба нагласити да се двадесетих година XX в. испољио таленат целе плејаде истраживача народног стваралаштва из различитих земаља. Представници ове генерације, често пријатељи - Јан Мукаржовски (1891 г. р.), Пјотр Богатирјов (1893 г. р.), Михаил Бахтин (1895 г. р.), Владимир Проп (1895 г. p.), Милован Гаваци (1895 г. р.), Роман Јакобсон (1896 г. р.) и други, делили су исте научне погледе и идеје, укључујући и методе „структурне анализе освајања фолклорне баштине" (Јакобсон).

Идеја карневализације и теорија дијалогизма Бахтина, где је текст „полазни податак и реалност”, значење речи, која „увек хоће да се чује”, актуализација - као резултат „максималне присности оног ко говори и адресата” - улоге фамилијарних жанрова и стилова, а такође експресивност као конституционално обележје говора, - највише се разоткривају у народној кул- 
тури. Код Богатирјова налазимо запажање о „фамилијарном комуницирању маскираних и прерушених” током покладних обичаја (Богатирјов 1971: 113). Бахтиново схватање континуитета фолклорне традиције која напаја културу и отвара перспективу „бесконачности” људског дијалога у складу је са тезом Богатирјова (и других представника Прашког лингвистичког кружока) о „сталној дифузији између високе и народне уметности” (Богатирјов 1971: 24). И у овом случају (као и са историјско-компаративном методом) идеје лингвиста прихватили су и стваралачки пренели на своју грађу њихове колеге - историчари књижевности и културе.

Проучавање народног позоришта оправдано се сматра централном темом целе научне делатности Богатирјова, што је признао и сам научник, нагласивши да је његова монографија о народном позоришту код Чеха и Словака „основна” у зборнику из 1971. Истраживањем позоришта Богатирјов је почео да се бави у младости, а 1922. објавио је у Берлину Программу изучения народного театра, коју је припремио заједно са Јакобсоном још 1919. у Москви. Управо на примеру народног позоришта њих двојица покренули су многе значајне проблеме естетике, између осталог повезаност уметничких средстава народног, средњовековног и барокног позоришта, а такође саоднос позоришне уметности и фолклора - посебно са ритуалом и магијским радњама. Зато је посебну пажњу Богатирјова привукла карневалска култура и „вашарски фолклор”, а чланак „Художественные средства в юмористическом ярмарочном фольклоре” јавио се, према њему, као „на неки начин допуна књиге о народном позоришту”. Разматрајући дијалошку природу текста народног вашара (узвици трговаца, узречице вашарских и вртешких ,дедица” и учесника народног вертепа, досетке Петрушке и сл.), прожет „веселим расположењем вашарске гомиле и нарочитом карневалском атмосфером, о којој је писао Бахтин”, Богатирјов закључује да овде „свуда влада култ смеха” као „потпуно фолклорна појава” (Богатирјов 1971: 9).

Истраживачи научне баштине П. Богатирјова оправдано запажају да је он знао у сваком конкретном фолклорном или етнографском факту уочити „законитости целокупне појаве” (Солнцева 2002: 6). Нужност да се пажња скреће на различите детаље наглашавао је и сам истраживач, говорећи о примени експерименталне анализе чињеница, „које можемо пратити сваког дана". Такав прилаз омогућио је дубинску анализу најразноврсније грађе и углавном лично засведочене фактографије коју налазимо у његовим радовима.

Своје схватање културе као полифункционалне појаве, корелативно Бахтиновом појму културне полифоније, Богатирјов је формулисао на основу дубинске анализе народних обичаја, а такође драмских обреда, и образложио у монографији Народный театр чехов и словаков. Књига под насловом Lidové divadlo české a slovenské (Praha, 1940) прво је изашла на чешком, и исте године била је одбрањена у Москви као докторат. Анализирајући народни карневал, аутор разматра његове саставне делове, односно позоришне елементе, који, према њему, „мање-више прожимају ритуале и обичаје, дечје игре, приповедање и сл.” (Богатирјов 1971: 23). 
Проучаваоци словенског фолклора, међу њима и Виктор Гусев, одређују карневал као масовни народни празник којим се испраћа зима, и истичу његову генетску везу са архаичним аграрно-магијским ритуалом за подстицање плодности. Празник се спроводи и данас, и његови називи у различитим словенским традицијама одражавају временски период између постова: рус. масляна; бел. сырніца, сырна нядзеля, запусты; укр. масниця, масляна, масляниця, колодка; болг. сирне поклади, ората, орадие, сирница; серб. сирнице; макед. сирница; хорв. masopust, pust; словен. pust; польск. zapusty; чешск. и словацк. mesopust (fašank, fašiand); сербо-лужицк. zapust, postnice (Гусев 1993: 109).

П. Богатирјов је такође обратио пажњу на календар, и посебно на „народне изведбе током поклада, карневале, када прерушени изводе велике или мале призоре”, а „у веселим покладним поворкама очитује се утицај градских карневалских процесија”. Нагласивши „посебну улогу хумора” и „необуздано весеље” за време покладних карневала и сеоских обредних игара, посебно ходање са медведом, Богатирјов запажа како је посматрао народне покладне забаве-,„ворачке” у Клатовској области или карневал у селу Дивље близу Софије, када су прерушени мечкар и медвед на ланцу опкољавали пролазнике и нису их пуштали док се не откупе. Овом приликом он износи закључке о значају маске у народним карневалима и истиче улогу импровизације у „драмским сценама на свадби, а такође у карневалским изведбама” као неопходни услов очувања традиције: „Па, кад се импровизација не би уносила у све облике народне уметности, традиција би постала шаблон” (Богатирјов 1971: 400).

Поглед П. Богатирјова уперен је углавном на обредну културу и народне обичаје у Закарпатју, у првом реду на народно позориште као маркантну особину традиције региона, која јарко рефлектује „основно” обележје позоришта - преображавање (звучно и визуелно опонашање), са магијском функцијом као „доминантном” (Богатирјов 1971: 14). Подстицање плодности је основно, према Богатирјову, семантичко обележје ритуала новогодишњег и божићног циклуса, нарочито у ритуалу полазника. Ову тему он је обрадио у обимном чланку „'Полазник' у южных славян, мадьяров, словаков, поляков и украинцев” (1932-1934) у часопису Lud Stowiański (Kraków) (Богатирјов 1932; Богатирјов 1934). У својим радовима, посвећеним компаративној анализи фолклорних врста „везаних за ритуал и магију” (нпр. формула за додељивање блага) више пута анализирао је ритуал, који објашњава јединство и „природну међусобну повезаност различитих врста народне уметности” (Богатирјов 1971: 430). У чланку „К вопросу о сравнительном изучении народного словесного, изобразительного и хореографического искусства у славян” (који посветио је Ф. Вољману), Богатирјов разматра формуле полазника, праћене обредним радњама (имитирање поза и опонашање домаћих птица и животиња - прављење чучњева, подскакивање, плесни покрети и сл.).

Приговарајући В. Чајкановићу - „неуспео покушај Чајкановића да објасни ритуал полазника из култа предака" (Богатирјов 1932: 109), Богатирјов ипак није негирао везу са култом предака, већ је сматрао да су „божићни ри- 
туали мешавина ритуала, од којих сваки тежи свом циљу". Због тога што су ритуали доживели „низ различитих религијских система”, објаснити грађу код једног словенског народа користећи исту код другог, убеђен је Богатирјов, „бива лакше и убедљивије” него код античких народа (Богатирјов 1932: 112) - захтев који се и дан-данас често занемарује.

Валерија Усачева, аутор чланка о полазнику у етнолингвистичком речнику Славянские древности (Усачева 2009: 128-131), као и у другим издањима (Усачева 1978), у свом раду „Театральные элементы в структуре славянского ритуального текста" у зборнику посвећеном Петру Богатирјову, између осталог запажа да је ритуал, упоредо са нестајањем магијско-сакралне суштине одржавао „традицијом наметнуту форму” и претварао се „у нешто друго” - управо у игру, спектакл, драму. На тај начин, драмски и позоришни елементи у структури свадбених ритуала, а такође карневалских поворки, полако почињу узимати превагу и замењивати обред, који постаје изведба и игра (Усачева 2002: 306); у исто време почетна семантика сачувана је на нивоу вербалне формуле.

Запажања Богатирјова у вези са формулама додељивања блага потврдила је Људмила Виноградова, истражујући проблем архаичних елемената у словенској народној култури. Управо на примеру изрека полазника она говори о ритуалним песмама као бајању, полазећи од конструкције двочлане компарације у формулама којима се жели благостање, а такође у враџбинама и магијским обредима као примарним (Виноградова 1978: 8-13).

На примеру „полазника” Богатирјов је формулисао принципијелни захтев синхроне анализе - да се пружи опис ритуала и његово схватање код сељака, и да се одреди генетска веза ритуала код Јужних Словена, Украјинаца, Словака, Пољака и Мађара (Богатирјов 1932: 114). Овај принцип нашао је образложење, свестрану употребу и даљи развој у радовима московске етнолингвистичке школе, у првом реду код Никите Толстоја, који је проценио идеје Богатирјова као „благовремене” и „убедљиве”. Заснивајући своју теорију реконструкције словенске духовне културе на тези о „заједничкој природи језика и културе”, као и „вишеслојевитости духовне културе”, Толстој образлаже могућности реконструкције користећи методе „унутрашње” (односно у оквиру једног макросистема или „културне породице”) и „спољашње” реконструкције, нагласивши да је тек после ових етапа „дозвољено” да се приђе грађи несродних језика, као и културама различитих система (Толстој 1995: 44).

У чланку „Элементы народного театра в южнославянской святочной обрядности", који је објавио московски часопис Театральное пространство (1979), Толстој поставља питање „настанка” и „доисторије” словенског народног позоришта, и позива се на монографију Богатирјова, а такође на „занимљив рад” Виктора Гусева „Истоки русского народного театра” (1977). Запажајући позоришне елементе у словенским ритуалима, Толстој истиче „најинтересантније” календарске ритуале, који чине један „доста чврст и консеквентан, мада и отворен систем" (Толстој 1995: 114). Анализа покладних маскирања у Јужној Србији и Македонији (цамалари, бабари, василичари, 
јешкари, русалије) сведочи, према аутору, у прилог „великој отворености” џамаларске и сличних изведби са ,јарко израженим позоришним особинама”, због чега цела изведба оставља утисак позоришног комада и разоноде, а истовремено чува „основни ритуални смисао - изазвати плодност”. На основу структурне анализе обредног текста, Толстој доноси закључак о „типичном” у народним обредима покладног циклуса синкретизму ритуалног и позоришног начела, и о могућности да се на том материјалу објасни „позната у науци теза" о развоју позоришта од ритуала према представи (Толстој 1995: 119).

Осим наведених божићних и новогодишњих ритуала Толстој проналази позоришне елементе у јужнословенском оказионалном ритуалу вучари, а такође у балканским обредима Тодорица и бадюак. Овом приликом он упоређује ритуале балтословенске традиције - литвански kalâdé, украјински колодий и српски бадњак, и на основу компаративне анализе запажа њихове паралеле и заједничке елементе, што отвара перспективу ширих типолошких и генетских веза (Толстој 1995: 123-148).

Ретроспективна анализа словенске духовне баштине, убеђује Н. Толстој, не само што је „принципијелно и теоријски” оправдана, него је таква метода „практички целисходна”. Толстој је наглашавао да „модерни прилаз” проблему тражи да се обави пут од „новог” према „старом”, од „савремености (XIX-XX ст.) према древности”. Само утврдивши перспективну еволуциону узастопност „у супротном смеру”, могао би да се и потребно је да се тај ред „преврне”, вративши читавом развојном процесу његову „историјску доследност”. Такав начин истраживања Толстој је метафорички одредио као „методу копања тунела са две стране, из далеке прошлости и из данашњег дана" (Толстој 2003: 562). Анализа писаних споменика, као и књижевних дела XVIII в. (Јован Рајић, Алексиј Везилић), а такође народне (вашарске, масовне, градске) књижевности у контексту такозване „треће културе”, односно „културе за народ”, и друга питања постављају се у вези с његовим основним „проблемима интересовања” - присутности народних митолошких веровања код Словена.

Интересантно је да исту метафору „копања тунела” налазимо и код Богатирјова. За њега је анализа фолклорног текста (вокалног, музичког, кореографског, усменог, драмског и др.) најпре означавала истраживање односа традиције и импровизације. Проблем, који је разматрао у више радова („Традиция и импровизация в народном творчестве”, 1964; „Импровизация и нормы художественных приемов на материале повестей XVIII века, надписей на лубочных куртинках, сказок и песен о Ереме и Фоме”, 1967), привукао је пажњу Богатирјова још у младости, када се заједно са Јакобсоном бавио проблемом колективног и индивидуалног начела у народном стваралаштву. Овом проблему враћао се касније и на фонду различите грађе, такође епске традиције (Богатирјов 1962; Богатирјов 2006). Анализом импровизације, сматра Богатирјов, може се објаснити „специфичност народних позоришних дејства”, а такође разумети њена улога „у професионалном позоришту”. У једном свом чланку наводи речи познатог редитеља Всеволода Мејерхолда: 
Основни проблем савременог позоришта јесте проблем очувања импровизаторске глумачке вештине у сложеној и тачној режисерској форми спектакла. Обично се дешава, као у басни: извучеш нос - западне реп... Разговарао сам недавно са Константином Сергеевичем [Станиславски]: и он слично мисли. Налазимо решење истог проблема, као градитељи тунела под Алпима: он креће с једне стране, а ја с друге, међутим негде на средини обавезно се морамо срести (Богатирјов 1964: 8).

Такав смер - у „сусрет” модерним прилазима и истраживачким методама, оригиналним идејама и принципима, актуелним проблемима и образложеним резултатима анализе, научним сумњама и светским признатим открићима, била је научна делатност Петра Богатирјова и Никите Толстоја - двојице истакнутих истраживача словенске културе.

\section{ЛИТЕРАТУРА}

Богатирјов 1932: П. Богатырев, «Полазник» у южных славян, мадьяров, словаков и украинцев. Опыт сравнительного изучения славянских обрядов, y: Lud Stowiański, t. 3, zeszyt 1, dział B, Kraków, 107-114.

Богатирјов 1934: П. Богатырев, «Полазник» у южных славян, мадьяров, словаков и украинцев. Опыт сравнительного изучения славянских обрядов II, y: Lud Stowiański, t. 3, zeszyt 2, dział B, Kraków, 212-273.

Богатирјов 1962: П.Г. Богатырев, Некоторые задачи сравнительного изучения эпоса славянских народов, у: IV Международный съезд славистов, Мaтериальl дискуссии, т. 1, Москва: Издательство Академии Наук СССР, 470-472.

Богатирјов 1964: П.Г. Богатырев, Традиция и импровизация в народном творчестве, Москва: Наука, 1-9.

Богатирјов 1971: П.Г. Богатырев, Вопросы теории народного искусства, Москва: Искусство.

Богатирјов 2006: П.Г. Богатырев, Функиионально-структуральное изучение фольклора (Малоизвестные и неопубликованные работы), /Составление, вступительная статья, комментарии С.П. Сорокиной, Москва: ИМЛИ РАН.

Виноградова 1978: Л.Н. Виноградова, Заклинательные формулы в календарной поэзии славян и их обрядовые истоки, у: И.М. Шептунов (ред.) Славянский и балканский фольклор. Генезис. Архаика. Традиции, Москва: Наука, 7-25.

Гусев 1993: В.Е. Гусев, Карнавал р., б., у., у: К.П. Кабашников (ред.), Восточнославянский фольклор: Словарь научной и народной терминологии, Минск: Навука і тэхніка, 108-109.

Зубрицка 1996: М. Зубрицька, Празьке лінгвістичне коло, у: М. Зубрицька (ред.) Антологія світової літературно-критичної думки XX cm., Львів: Літопис, 324-325. 
Мукаржовски 2002: Я. Мукаржовский, О Богатыреве, у: Л.П. Солнцева (ред.) Петр Григорьевич Богатырев. Воспоминания. Документы. Статьи, Санкт-Петербург::Алетейя, 16-18.

Некрилова 1993: А.Ф. Некрылова, Карнавальность $p$., Карнавальнасць б., Карнавальність y., у: К.П. Кабашников (ред.), Восточнославянский фольклор: Словарь научной и народной терминологии, Минск: Навука і тэхніка, 110.

Речник: Rečnik književnih termina, fototipsko izdanje, (ur.) D. Živković, Бања Лука: Романов.

Солнцева 2002: [Л.П. Солнцева] От составителя, у: Л.П. Солнцева (ред.) Петр Григорьевич Богатырев. Воспоминания. Документы. Статьи, Санкт-Петербург.: Алетейя, 5-15.

Толстој 1995: Н.И. Толстой, Язык и народная культура. Очерки по славянской мифологии и этнолингвистике, Москва: Индрик.

Толстој 2003: Н.И. Толстой, Очерки славянского язычества, Москва: Индрик. Усачева 1978: Обряд «полазник» и его фольклорные элементы в ареале сербохорватского языка, у: И.М. Шептунов (ред.) Славянский и балканский фольклор. Генезис. Архаика. Традииии, Москва: Наука, 27-47.

Усачева 2009: В.В. Усачева, Полазник, у: Н.И. Толстой (ред.) Славянские древности. Этнолингвистический словарь, т. 4, Москва: Международные отношения, 128-131.

Оксана Микитенко

ВКЛАД ПЕТРА Г. БОГАТЫРЕВА И НИКИТЫ И.ТОЛСТОГО В ИЗУЧЕНИЕ КАРНАВАЛИЗАЦИИ В ФОЛЬКЛОРЕ СЛАВЯН

(Резюме)

Вклад Петра Г. Богатырева и Никиты И. Толстого в изучение карнавализации в народной культуре, и в частности поэтики карнавализации в фольклоре, проявляется как на теретико-методологическом и предметно-конкретном плане разносторонних научных исследований, так и со стороны теоретических заключений, а также в мастерстве увидеть в любом фольклорно-этнографическом факте (напр., полазник, бадняк) закономерности проявления диалектной народной традиции, с учетом соотношения «низкой» и «высокой» культуры. Принцип „функционально-структурального"изучения фольклора, сформулированный П. Богатыревым в 1929 г. в знаменитой книге о магических действиях, обрядах и верованиях в Подкарпатской Руси, а также положения его классических трудов о народном театре и о театральных элементах в структуре славянского обрядового текста, в дальнейшем нашли продолжение и развитие в трудах Н. Толстого (и московской этнолингвистической школы), став доказательством единства народной традиции. Ритуал, рассмотренный в рамках семиотики, позволил дать семантическую интерпретацию синкретичного по своей природе фольклорного текста и релевантных с точки зрения карнавализации обрядовых магических элементов (ритуальный смех, маска, антиповедение, диалог, обсценная лексика и под.). 